\title{
New Perspectives on International
}

\section{Environmental Law}

The United Nations Conference on the Human Environment, which met in Stockholm in 1972, sought to clarify the obligations of states to protect the environment of the entire planet and to develop institutions capable of focusing and pursuing those concerns. ${ }^{1}$ The Conference was a benchmark in indicating changing perspectives on international environmental affairs, but its immediate effect on international law was necessarily marginal. A beginning was made, but legal analyses of global environmental problems are still characterized by piecemeal, overlapping, and often contradictory classifications.

This Note will suggest a basic conceptual framework and use it to assess both the adequacy of the existing legal order and means of improving the prescription and application of international environmental law. ${ }^{2}$ The analysis will be grounded on three basic observations. First, the traditional international legal order already has available numerous provisions for achieving some environmental goals, including particularly the protection of national resources and freedom of access for all states to the common resources of the earth. Second, the threat of a global environmental crisis has outmoded this pattern of prescription and application in several respects, although governments have begun to perceive the imperative of a less state-centered perspective in their prescription of international environmental law. Third, given the character of the international system today, there is a compelling need for states to undertake increased and strengthened initiatives for the application of international environmental law.

1. For details of the Conference, see REPORT OF THE UNITED NATHoNs CoNferevce oN THE Human EnviroNiment, U.N. Doc. A/Conf. 48/14 (1972) [hereinafter cited as Reront]. One hundred and thirteen nations including the People's Republic of China attended. but the Soviet bloc countries (with the exception of Romania and Yugoslavia) were not represented, in protest against use of the "Vienna formula" which enabled W'est Germany but not East Germany to attend. See also B. WARD \& R. DuLos, ONLY ONE EARTi 207 (1972).

2. For purposes of this Note, "prescription" is the crystallization of general policiesby agreement, custom, or otherwise-in continuing community cxpectations. "Application" refers to the final characterization of concrete circumstances according to prescriptions, the enforcement of principles in practice. For more details, see ifcDougal, Lasswell \& Reisman, The World Constilutive Process of Authorilative Decision, $19 \mathrm{~J}$. LEGAL ED. 253, 403, 423-26, 429-32 (1967). 


\section{The Inherited Legal Order of the Environment}

"International environmental law" is a new concept and its scope remains unclear. Environmental issues encompass economic and social as well as strictly ecological problems. These issues may be international for one or more of at least five reasons: (1) actions in one country may have transnational effects; ${ }^{3}$ (2) certain practices by states or their nationals may have deleterious consequences for the common resources;" (3) environmental programs may result in distortions of international trade or development assistance; ${ }^{5}$ (4) specific environmental problems are common to enough countries to recommend their resolution through international cooperative efforts; ${ }^{6}$ and (5) because of their great genetic, aesthetic, cultural, or historical significance, some endangered species, objects, or monuments within particular sovereign states warrant international measures for their protection. ${ }^{7}$

There is thus an international environmental dimension to virtually every question in the global decision process. If decision-makers are to arrive at more effective political choices, however, it is necessary to identify more specifically those international problems with the most immediate environmental impacts.

The central problems can be framed in terms of three basic sets of principles dealing with the use and enjoyment of resources: principles of competence over resources, principles regulating their employment in use, and principles governing realization of benefit. Use of the concept of resources (including human resources) permits the comprehensive treatment of environmental issues, uniting ecological criteria with traditional property considerations. This formulation thereby encompasses both the legal distinctions between ownership and use and the underlying economic concepts of allocation and distribution. Within this theoretical framework, consequently, principles from traditional fields of international law can be combined into a coherent order of "international environmental law."

3. See pp. 1665-66 infra for examples of acts having harmful impact across statc lines for which liability has been assigned.

4. For a definition and examples of common resources, referred to in international legal parlance as inclusive resources, see pp. 1662.63 infra.

5. See, e.g., p. 1669 infra; RerORT 101.05.

6. See, e.g., p. 1671 infra. Many problems of urban growth and population distribution are of this type. See REPORT 89-95.

7. Possible examples include whales and other endangered species, wilderness areas, the city of Venice, and Greek vases. For recommendations for action on such resources, see REPORT 22-31. 


\section{A. Principles of Competence Over Resources}

"Competence" over resources may be defined as comprehending the right to prescribe and apply law in relation to such resources. The UN Declaration on the Human Environment summarizes the regime of competence:

States have, in accordance with the Charter of the United Nations and the principles of international law, the sovereign right to exploit their own resources pursuant to their own environmental policies, and the responsibility to ensure that activities within their jurisdiction or control do not cause damage to the environment of other States or of areas beyond the limits of national jurisdiction. ${ }^{8}$

There is a fundamental tension in this system: On the one hand states have a sovereign right to manage, develop, allocate, distribute, and otherwise control their own resources; but, somewhat analogous to the sic utere principle in domestic law, ${ }^{3}$ they also have the responsibility not to injure interests beyond their borders.

These rights and duties vary depending on whether the resources in question are exclusive or inclusive-that is, whether they are "owned" by the state or are instead part of the res communes, to be shared with all other states. Exclusive resources include the land masses ${ }^{10}$ and their closely proximate waters (in particular, internal waters ${ }^{11}$ and the terri-

8. Declaration of the United Nations Conference on the Human Environment, in REPORT at 2, Principle 21 [hereinafter cited as Declaration].

9. Sic utere tuo ut altenum non laedas (use your property so as not to injure that of another) has been described as one of those "general principles of law recognized by civilized nations" which the International Court of Justice is to apply by virtue of Article 38 of its Statute. See 1 Oppenheim, INTernational Law 346.47 (8th ed. Lauter. pacht, 1955). The extent of the prohibition of the abuse of rights, however, is not at all certain, and it must be left to international tribunals to apply and develop this still-controversial doctrine by reference to individual situations. Id. at 347 . Sec, e.s., the Trail Smelter Arbitration, 3 U.N.R.I.A.A. 1938 (1941), 35 A.. J. LNT'L L. 694 (1941); p. 1665 infra.

10. International law recognizes five principal modes whereby a state can acquire title to and exercise exclusive control over territory: discovery and occupation, conquest or annexation, accretion, prescription, and cession. H. BRIGGs, TuE LAW OF NAtross 250 (2d ed. 1952). See M. McDougad, H. Lasswell \& I. Vhasic, Law aNd Punlic Onder iv SPACE 828-67 (1963). This principle of exclusive territorial sovereignty is fundamental to the U.N. Charter. See U.N. CharTer art. 2, para. 4.

11. "Internal waters" are defined as "waters on the landward side of the territorial sea." Convention on the Territorial Sea and the Contiguous Zone, done April 29, 1958, [1964] 15 U.S.T. 1606, T.I.A.S. No. 5639, 516 U.N.T.S. 205, art. 1. These viaters include "historic bays" and bays with straight base or closing lines of less than twenty-four nautical miles, as well as ports and harbors. Id. arts. 7 and 8 . Roadsteads also come within the regimes of either internal waters or on the territorial sea. Id. art. 9. These internal waters are legally assimilated to their adjacent land masses and are therefore deemed coastal states' own resources. See M. MfcDougat \& W. Burke, Tie Punlic Onden. OF THE OCEANS 64 (1962). 
torial sea ${ }^{12}$ ), their superjacent airspace, ${ }^{13}$ the continental shelf, ${ }^{14}$ and certain genetic, aesthetic, and cultural resources ${ }^{15}$ within these areas. Inclusive resources include the oceans, the airspace above the oceans, and the ocean floor, ${ }^{16}$ the void of space and celestial bodies, ${ }^{17}$ inter-

12. The Convention on the Territorial Sea and the Contiguous Zone, supra note 11 , art. 1, recognizes that "the sovereignty of a State extends. beyond its land territury and its internal waters to a belt of sea adjacent to its coast, described as the territorial scit." There has been much recent disputc over the width of the territorial sea, but no country disputes the contention that the marginal sea belonging to a constal statc embraces a belt of at least three maritime miles. The sovereignty that a state may exercise over this area, however, is subject to certain restrictions-most significantly, the right of "innocent passage." See id. arts. 14-23. This topic is under extensive current review in the context of the upcoming U.N. Conference on the Law of the Sea. See S. LAY, K. Churchill \& M. Nordquist, New Direchons in the LAw of the SeA: Docunents 737 (1973).

13. Access to such airspace is entirely dependent upon the subjacent state, which is free to decide unilaterally whether or not to admit foreign aircraft and under what conditions. See Convention on International Civil Aviation (the "Chicago Convention") done December 7, 1944, 61 Stat. 1180 (1947), [1944] X.I.A.S. No. 1591, 15 U.N.T.S. 295, art. 1; M. MCDougal, H. Lasswell \& I. Vlasic, supra note 10, at 254-57.

14. The continental shelf is defined as the seabed and subsoil adjacent to the coast but outside the area of the territorial sea "to a depth of 200 metres or, beyond that limit, to where the depth of the superjacent waters admits of the exploitation of the natural resources of the said areas." Convention on the Continental Shelf, done April 29, 1958, [1964] 15 U.S.T. 471, T.I.A.S. No. 5578, 499 U.N.T.S. 311, art. 1. The Con. tinental Shelf Convention specifies that rights over the shelf are "exclusive." If a coastal state does not explore or exploit its resources, no one else may do so "without the express consent of the coastal State." Id. art. 2. In the North Sea Continental Shelf Caise, [1969] I.C.J. 3, the International Court of Justice held that the basic provislons of this convention codified preexisting customary international law. Thus, they reflect norms binding on all states rather than only the adherents to the treaty.

15. See note 7 supra. The status of genetic, aesthetic, and cultural resources has traditionally been determined by that of the area or medium within which they are lo. cated. Since most are situated on the land masses (although, of course, a multitude of creatures critical to ecological systems live in the sea), they have been treated as subject to the exclusive competence of the country possessing jurisdiction over that territory.

16. Ships of all states may traverse the high seas almost entirely frec of prohibition by any state or group of states. See M. MCDOugaL \& W. BuRkE, supra note 11, at 767. The conventional regime regarding free use of the airspace above the high seas is very much the same. See Convention on the Regulation of Aerial Navigation, done Octobet 13, 1919, corrected text in U.S. Dep't. of State Pub. No. 2143 (1914), and the 1944 Chicago Civil Aviation Convention, supra note 13. Since the seabeds and the occan floor were only recently opened to direct access by man, there are few explicit prescriptions regarding competence over them. Their main use has heretofore been for laying long distance communications cables and no one has challenged the permissibility of their use for this purpose. See M. McDougat \& W. BukKE, stpra note 11, at 780.

Explicit recognition of inclusive competence in regard to the three areis is found in the Convention on the High Seas, done April 29, 1958, [1962] 13 U.S.T. 2912, T.I.A.S. No. 5200,450 U.N.T.S. 82 , art. 2, which provides for the exercise by both coistal and noncoastal states of "(1) Freedom of navigation; (2) Freedom of fishing; (3) Ireclom to lay submarine cables; (4) Freedom to fly over the high seas."

17. The inclusive character of the void of space and celestial bodies has becn estab. lished by the past practice of states and by concomitant expressions of expectations by different community spokesmen. See M. MIcDougAL, H. LAsswell, \& I. VIASIC, supra note 10, at 226-27. A UN General Assembly resolution in 1961, for example, provided that outer space and celestial bodies "are free for exploration and use by all States ... and are not subject to national appropriation." International Cooperation in the Pcaceful Uses of Outer Space, G.A. Res. 1721, 16 U.N. GAOR Supp. 17, at 6 (1961). See Declaration of Legal Principles Governing the Activities of States in the Exploration and Use of Outer Space, G.A. Res. 1962, 18 U.N. GAOR Supp. 15, at 15 (1963). Sec generally Question of Peaceful Uses of Outer Space, G.A. Res. 1348, 13 U.N. GAOR Supp. 18, at 5 (1958); International Cooperation in the Peaceful Uses of Outer Space, G.A. Res. 1472, 14 U.N. GAOR Supp. 16, at 5 (1959); Question of General and Com. 
national rivers, ${ }^{18}$ polar areas, ${ }^{19}$ and some florw ${ }^{20}$ and stock ${ }^{21}$ resources. The patterns of legal order dealing with inclusive and exclusive resources are not symmetrical. The use of exclusive resources is subject to both prescription and application by a single state. Inclusive resources, which are potentially shareable but not necessarily shared in fact, are subject to a legal system of principles and practices which are collectively derived but which may or may not be collectively applied.

plete Disarmament, G.A. Res. 1884, 18 U.N. G.AOR Supp. 15, at 13 (1963). Equality of opportunity for all states in the use of and competence oicr this resource was in. corporated into treaty form in 1967. Treaty on Principles Governing the Actisities of States in the Exploration and Use of Outer Space, Including the Moon and Other Celestial Bodies (the "Outer Space Treaty"), opened for signature January 27, 1967, T.I.A.S. No. 6347, text in 6 INT'L Leg.AL M.ATERIALS 380 (1967).

18. The Statute on the Regime of Navigable Waterways of International Concern, done April 20, 1921, 7 L.N.T.S. 51, provides that cach of the contracting states "shall accord free exercise of navigation to the vessels flying the flag of any one of the other Contracting States" and provides further that "no distinction shall be made between .. the different riparian states" or even "between riparian and non-riparian states." Id. arts. 3, 4. Where the shared use of international rivers confliets with other activi. ties of riparian states (e.g., power, industrial uses, dredging, clearing, and maintcnance). the principle of the "community of interest of riparian States" governs. See Case of the Territorial Jurisdiction of the International Commission of the River Oder, [1929] P.C.I.J., ser. $A$, No. 23 , at 27.

19. Due to divergences in historical development, there are differences in the international legal status of the Arctic and Antarctic regions. The original pattern in relation to the Antarctic was and has remained inclusive. Intarctic Treaty, done December 1, 1959, [1961] 12 U.S.T. 794, T.I.A.S. No. 4780, 402 U.N.T.S. 71. The Arctic land masses, however, have traditionally been regarded as sufficiently comparable to the other land masses of the earth to be subject to exclusive appropriation. The . Irctic basin, nevertheless, and despite certain Soviet claims to the contran, has becn subject only to inclusive access and competence. See M. MIcDougat, H. LAssivel., \& I. Vilistc, supra note 10 , at 792 .

20. Professor S. yon Ciriacy-Wantrup, in ResourCe Covservation: Ecovomics AND Policies 35 (1952), divides resources into two major groupings: the rencwable or "flow," and the non-renewable or "stock" resources. Professors IICDougal, Lassivell and V'lasic. supra note 10, at 779, add a third category of "spatial extension" resources for "those te. sources whose most distinct characteristic is their utility as media of transportation and communication." They cite as cxamples land and ocean surfaces, airspace and outer space. Id.

"Flow" resources are themselves divisible into those which are not significantly affected by human action, e.g., cosmic rajs, solar radiations, gases, winds, oceanic currents and tides, minerals dissolved in the waters, and gravitational and magnetic forces and those which are. The latter class is further subdivisable into those resources affected by human action which have a "critical zone" (a range of occurrence and reproduction, which, if reduced below a certain level, will continuc to decrease in an economically irreversible fashion), e.g., pelagic scals, whales, and salmon, and those which do not, e.g., some ocean fisheries and waters of international rivers. See id. at 777-81; CiriacY-WanTrup, supra, at 38-40. All these flow resources have iraditionally been considered shareable and open to inclusive use and regulation on the basis of equality of opportunity. See, e.g., note 18 supra (international rivers) and note 33 infra (whales).

21. Minerals are the most important stock resources and have to date most often been found within the territory of nation states. The same considerations and decisions which have made the land masses and continental shelf subject to exclusive appropriation, therefore, also embrace these resources. See Right to Exploit Freely Natural Wealth and Resources, G.A. Res. 626, 7 U.N. G.AOR Supp. 20, at 18 (I9j2); Permanent Sovereignty over Natural Resources, G.A. Res. 1803, 17 U.N. G.AOR Supp. 17. at 15 (1962); Permanent Sovereignty over Natural Resources, G.A. Res. 2158, 21 U.N. GAOR Supp. 16, at 29 (1966). 


\section{B. Principles Regulating Employment in Use}

Through its present prescriptions, the international legal order has sought to minimize the loss by states of their own resources and to prevent interference with states' use of the common resources. The existing principles of this sort can be divided, for purposes of analysis, into two categories: those restricting injurious and those facilitating productive and harmonious employment.

\section{Restricting Injurious Employment in Use}

Traditional international law contains a number of principles allowing states to protect themselves from environmental damage threatening their own territories or their interest in the common resources and assigning liability should such damage occur. Until very recently, however, no similar principles existed for the protection of the common resources per se.

In order to protect itself from environmental damage, a state may invoke such traditional international law doctrines as those of "self defense," "self preservation," and "security," as well as the somewhat less-defined principle of "good neighborliness." 22 Under the varied doctrines of "self-help," a state confronted with a major threat to its exclusive resource interests is permitted to exert the "necessary and proportional" force to avert the danger or to abate its effects. ${ }^{23} \mathrm{In}$. ternational law also recognizes contiguous zones within which states may exercise limited control over inclusive resources for particular purposes. ${ }^{24}$ In addition, coastal states have certain other rights of

22. See U.N. Charter art. 51 and the complementary provision prohibiting "the threat or use of force" in id. art. 2, para. 4.

These self-help prescriptions are supplemented by the principle of "good neighbor. liness," which obligates states to try to reconcile their interests with the interests of neighboring states. This doctrine is probably most highly developed in the law of international rivers, where a broad standard of recognition and respect for the multiple and alternative uses of the waters has evolved. See, e.g., Case of the Territorial Juris. diction of the International Commission of the River Oder, [1929] P.C.I.J., ser. $A$, No. 23 , discussed note 18 supra.

23. "Necessary and proportional" measures always depend for their justification upon the urgency of the need for protection. The question of self-help in an ccological context was raised most dramatically in the Torrey Canyon catastrophe. The Royal sir Force bombed the stranded and damaged tanker in international waters in an altempt to halt further spills of oil which were damaging the English Coast. See Brown, Thic Lessons of the Torrey Canyon, 21 CuRrent LEGAL Prob. 113 (1968); Utton, Protective Measures and the 'Torrey Canyon', 9 B.C. IND. \& Comm. L. Rev. 613 (1968). For a more expansive view of international law doctrines of protection under similar circumstances, sec Hardy, International Protection against Nuclear Risks, 10 INT'L \& CoM1. L.Q. 613 (1968); McDougal \& Schlei, The Hydrogen Bomb Tests in Perspective: Lawful Measure for Security, in M. McDougal \& Associates, Studies in World Punlic Ordek 279 (1960).

24. Contiguous zones are unlike territorial seas in that thcy are not subject to exclusive appropriation by coastal states; rather, they are areas over which a state may exercise specialized jurisdiction for specific purposes having direct effects on the ter- 
abatement beyond their national jurisdictional limits. These rights derive from the principle of "impact territoriality," which establishes the competence of a state with respect to events which occur within or have impacts upon its territorial base. ${ }^{25}$ This principle was the legal basis for the recent Intergovernmental Marine Consultative Organization "Public Law" Convention, which authorizes states parties to take corrective measures on the high seas to prevent or abate danger to their coastlines arising out of oil pollution casualties. ${ }^{20}$

On the issue of liability, a continuous flow of international decisions, conventions, and practices indicates acceptance of a standard of strict liability among states for damage caused by or deprivations resulting from manipulation of environmental variables. This standard has been developed by extension of three well-known cases: The Trail Smelter arbitration, in which an international tribunal found Canada liable for fumes emanating from a smelter located in British Columbia and doing damage in the state of Washington; ${ }^{27}$ the Corfu Channel

ritorial sea, internal waters, or land mass of the state. The Consention on the Terri. torial Sea and the Contiguous Zone, supra note 11, art. 1, allows control over a maximum of twelve maritime miles for purposes of prevention of infringements of "custom, ficcal, immigration or sanitary regulations." In addition to control over specific contiguous zones, but based on the same underlying principle of impact territoriality, countries have from time to time claimed and been allowed authority over various supplementary zones-customs zones, fisheries zones, security zoncs-of greater than twelve nautical miles. See M. McDougal \& W. Burke, supra note 11 , at 584-606.

25. The territoriality principle is thus similar to the nationality principle, which confers competence on a state when its nationals are actors, and to the related "passive personality" principle, which does so when its nationals are victims. See p. 1670 in/ra. It is somewhat narrower than the "protective principle" underlying the various forms of self-help, note 22 supra, since the latter extends a broad mante of competence in relation to events affecting various vital interests of the statc as a whole.

26. International Convention Relating to Intervention on the High Seas in Cases of Oil Pollution Casualties, done November 29, 1969, text in 9 INT'L LEGal Minenuls 2j (1969). The "Public Law" Convention, along with its companion "Private Law" Con. vention (International Convention on Civil Liability for Oil Pollution Damage, done November 29, 1969, text in id. at 45), was finalized and opened for sigmature and accession at the IMICO International Legal Conference on Marine Pollution Damage. The convention has not yet come into force; but even were it to do so, it seems to clarify rather than to add to traditional rights of abatement. The basic standards of "necessity" ("meas. ures shall not go beyond what is reasonably necessary to achieve the end mentioned," Public Law Convention, art. 5, para. 2) and "proportionality" ("measures taken by the coastal State . . . shall be proportional to the damage actual or threatened," id. art. 5. para. 1) are retained, as is the antecedent condition that the thrcat to the coastline or related interests of a coastal state must be "grave and imminent" and "reasonably . . . expected to result in major or catastrophic consequences." Id. art. 1 .

27. 3 U.N.R.I.A.A. 1938 (1911), 35 AM. J. INT'L L. 684 (1911). The arbitral tribunal explained its reasoning in a much-quoted passage:

Under principles of international law, as well as of the law of the United States. no State has the right to use or permit the use of its territory in such a manner as to cause injury by fumes in or to the territory of another or the properties or persons therein, when the case is of serious consequence and the injury is established by clear and convincing evidence....

The tribunal holds that the Dominion of Canada is responsible in international las: for the conduct of the Trail Smelter.... [I]t is the duty of the Government of the Dominion of Canada to see to it that this conduct should be in conformity with the obligation of the Dominion under international law as herein determined.

The Trail Smelter shall be required to refrain in the future from causing damage 
case, in which the International Court of Justice held Albania responsible under international law for damage to British ships from mine explosions in Albanian territorial waters; ${ }^{28}$ and the Lac Lannoux arbitration, where it was said that France would be strictly liable if, due to its hydroelectric utilization of a French lake, damage resulted to waters draining into Spain. ${ }^{20}$ Strict liability among states has similarly found expression in several multilateral conventions. ${ }^{30}$ Such liability has usually been enforced in the first instance by and against states, leaving to national legal systems its assertion directly against private parties.

\section{Facilitating Productive and Harmonious Employment in Use}

The prevailing pattern of legal principles concerning productive and harmonious use of resources is relatively simple. Each state determines the appropriate means of utilization of its own exclusive resources, although accommodations may be worked out where these regulations affect the interests of other states or their nationals. With regard to the inclusive resources, however, cooperative behavior is more organized: All states are accorded equal opportunity to use shareable resources, such as the oceans; no state may assert general competence over the vehicles, enterprises, and nationals of other states in these areas; and most states have consented to follow or have customarily followed uniform regulations concerning certain activities.

through fumes in the State of Washington. To avoid such damage the operations of

the Smelter shall be stubject to a regime or measure of control as provided in the

present decision. Should such damage occur, indemnity to the United States shall

be fixed in such manner as the governments acting under the Convention maly agree upon.

28. [1949] I.C.J. 4, 22. The court had to decide whether Albania was responsible under international law for the explosions and resultant damage and whether the United Kingdom had violated the sovereignty of the Pcople's Republic of Albania by reison of certain acts (including subsequent mine sweeping) by the Royal Navy in Albanian waters. The court rendered judgment in favor of the United Kingdom on both questions.

29. 12 U.N.R.I.A.A. 281 (1957), 53 AM. J. INTL L. 156 (1959). The arbitral tribumal held for France after finding that there would be full restitution of the diverted waters if the proposed electricity project were carried out. It made it clear, however, that strict liability would have governed in the event of a finding for Spain:

It would then have been argued that the works would bring about a definitive pollution of the waters of the Carol or that the returned water would have a chemical composition or a temperature or some other characteristics which conld injure Spanish interests. Spain could then have claimed that her rights had been impaired.

Id. at 303, 53 AM. J. INT'L L. at 160-61.

30. See, e.g., article 3 of the IMCO "Private Law" Convention, supra note 26, which provides that shipowners "shall be liable for any pollution damage caused by oil which has escaped or been discharged from the ship"; article 7 of the Outer Space "I"reaty, supra note 17, which provides that a state launching an object into space "shall be internationally liable for damage to another State Party to the Treaty or to its natural or juridical persons by such object"; and the new Convention on International Lia. bility for Damage Caused by Space Objects, March 29, 1972, art. 2, text in 66 Ast. J. INT'L L. 702 (1972), which provides that a launching state "shail be absolutely liable to pay compensation for damage caused by its space object on the surface of the earth or to aircraft in flight." 
A variety of diverse principles have combined to produce this order. Facilitating productive employment has traditionally been thought of in terms jointly of conservation and apportionment. The various fisheries, $^{31}$ pelagic sealing, ${ }^{32}$ and whaling ${ }^{33}$ conventions, are examples of international agreements for this purpose. Providing for the harmonious employment in use of resources has required clarification of principles of jurisdiction and limitations thereon. Principles of jurisdiction over vessels, ${ }^{34}$ spacecraft, ${ }^{35}$ and aircraft ${ }^{36}$ traveling beyond national

31. The Convention on Fishing and Conservation of the Living Resources of the High Seas, done April 29, 1958, [1966] 17 U.S.T. 138, T.I....S. No. 5969. 559 L....I'.S. 28.5, sets up an order whereby all states are granted the right to fish, subjext to certain limitations. The two most basic restrictions are: First, states whose mationals atc cllgaged in fishing in areas where other nationals are not thus engaged shall adopt neces. sary measures for conservation purposes and shall apply these to their nationals (art. 3); and second, when nationals of two or more states are engaged in fishing the same stock in any area, they shall, at the request of any one of them, negotiate necessary conservation measures and apply them to their nationals (art. 4).

For examples of international accommodation with regard to specific areas and types of fisheries, see International Convention for the High Seas Fisheries of the North Pacific Ocean, May 9, 1952, [1953] \& U.S.T. 380, T.I.A.S. No. 2786, 20j U.X.T.S. 65; International Convention for the Northwest Atantic Fisheries, done Februars 8, 1949. [1950] 1 U.S.T. 477, T.I.A.S. No. 2089, 157 U.N.T.S. 157. with sereral protocols up to that of November 29, 1965, [1970] 21 U.S.T. 576, T.I..A.S. No. 6841; North-East . Itlantic Fisheries Convention, January 24, 1959, 486 U.N.T.S. 15\%, 1963 U.K.T.S. 68. For conventions on particular species, see S. LAy, R. Ciunciuld \& M. Nondeuist, supra note 12. at 406 passim.

32. The Convention between the United States, Great Britain, Russia and Japan for the Preservation and Protection of Fur Seals, July 7,1911 . 37 Stat. $15+2$ (1911-13). T.S. No. 564, 104 B.F.S.P. 175, with sequels of December 8, 1942, 58 Stat. 1379 (1944), E.. I.S. No. 415, 26 U.N.T.S. 364, and of February 9. 1957, [1957] 8 U.S.T. 2283. T.I.I.S. No. 3948 , 314 U.N.T.S. 105, prohibits pelagic sealing and sea ottering on the high seas and restricts such activity to areas within the control of the United States. Japan. and Russia. Canada and Japan are to receive percentages of the gross catch of the Unitcd States and Russia as well as lump-sum payments from the United States in return for refraining from sealing, an otherwise lawful activity in the oceans. Similarly, each of the other three countries is to receive percentages of the Japanese catch.

33. The International Convention for the Regulation of Whaling. December 2, 1946 , 62 Stat. 1716 (1948), T.I.A.S. No. 1849. 161 U.N.T.S. 72, art. 3, establishes an International Whaling Commission which is empowered to set up various regulations, including fixing the total maximum catch of whales by all parties. It is, however, specifically denied the authority to apportion this catch among the states.

34. A merchant vessel on the high seas or a ship of war anywhere is assimilated to the territory of the state in which it is registered; that state, therefore, retains jurisdiction over it. See H. Bricgs, supra note 10, at 339 . The jurisdiction of a state orer its vessels in foreign national waters is concurrent with that of the coastal state (with certain qualifications, such as distinctions between civil and criminal questions and exceptions for "distress" and "innocent passage"). See id. at 361. Neither in shared nor in national waters, however, does a state entirely lose control over its vessels. On the high seas there is universal jurisdiction with regard to crimes of piracy. See id. at 389 . These jurisdictional prescriptions are supplemented by a host of ancillary regulatory rules. such as those dealing with safety and navigation. Sec, c.g., Intcrnational Regit: lations for the Prevention of Collisions at Sea, approved May 17-June 17. 1960. [1965] 16 U.S.T. 794, T.I.A.S. No. 5813; International Convention for the Safety of Life at Sea, June 17, 1960, [1965] 16 U.S.T. 185, T.I.A.S. No. 5780, 536 U.N.T.S. 27; done April 9, 1965, [1967] 18 U.S.T. 411, T.I.A.S. No. 6251.

35. The Outer-Space Treaty provides that a state on whose registry an object launched into space is carried "shall retain jurisdiction and control over such object. and over any personnel thereof, while in outer space or on a celestial body:" Outer Space Treaty, supra note 17, art. 8.

36. The International Air Services Transit Agreement ("Two Frcedoms"), opened for signature December 7, 1944, 59 Stat. 1693 (1945), E..1.S. No. 487, 81 U.N.T.S. 339, art. 
boundaries have been derived both by custom and international agrecment. Similarly, prescriptions popularly described as "private international law" confer jurisdiction on the courts of a state to protect its nationals and other interests from injury, including injury consummated beyond its boundaries. ${ }^{37}$ Finally, those principles traditionally labelled "responsibility of states" impose certain limitations on the competence of states over aliens and their property with respect to events otherwise within their jurisdiction. ${ }^{38}$

Although specific provisions in this area of law have varied somewhat with changes in technology, the underlying principles have long retained the acceptance of the international community. As a result, for centuries there has been little attempt to carve up the commons or to monopolize competence over them. They remain allocated to inclusive enjoyment, regardless of the actual distribution of the benefits derived from them.

\section{Principles Governing Realization of Benefit}

Along with questions of who can make and apply law with respect to resources, there are also problems concerning who shall derive benefit from such resources and in what capacity these rights shall be enjoyed. While realization of benefit is largely dictated by techno. logical capacity, the result is also partially determined by broader issues of relations among states and of human rights in relation to resources.

\section{Relations Among States}

The regime of national control over exclusive resources and of equality of opportunity with regard to shareable resources must be viewed in the context of the practical limitations on the power and capabilities of states. Many countries in the world today are able neither to exploit

$1, \S 5$, expresses the jurisdictional principles governing aircraft in a negative fashion; it allows any state to revoke a certificate or permit "in any case where it is not satis. fied that substantial ownership and effective control are vested in the nationals of a contracting State."

37. This set of prescriptions and practices is often known in the United States as the "conflict of laws" but in most other countries is referred to as "private international law." It traditionally includes three general subjects: the bases on which a court will assert jurisdiction over the persons and the subject-matter, the effect to be given to judgments rendered by courts of other states, and the principles governing choicc of law. See H. Steiner \& D. Vagts, Transnational Legal Problems 79 (1968).

38. Prescriptions of "responsibility of states," also frequently referred to as those of an "international minimum standard," have proved difficult to define in a number of current efforts to "codify" or "restate" them. They constitute a sort of "international bill of rights" as to the person and property of alicns. See generally id. at $275 \cdot 425$. 
their own resources nor to enjoy the use of the commons without the assistance and cooperation of other states.

It is here that the traditional principles of international law, which focus on rights rather than capabilities, are particularly inadequate. Solutions to the conflicts between the "have-nots" and the "haves" are not provided for by the established principles concerning the use and control of resources. ${ }^{39}$ The developing nations fear that the great commercial powers will use their advanced technology to deplete the resources of the commons upon which they too depend. The frequent controversies over fishing rights are reflections of this concern. ${ }^{\text {to }}$

There is also a fear that the growing environmental concerns of the advanced industrial states will be implemented at the expense of the continued economic and social development of the poorer countries. Both the World Bank (IBRD) and the United States Agency for International Development (AID), for example, have now formulated environmental criteria which are to be used in evaluating requests for development assistance loans. ${ }^{11}$ Such actions can lend themselves to accusations that the poor are being made to pay for the past environmental mistakes of the rich.

\section{Human Rights in Relation to Resources}

The problems surrounding realization of benefits from the earth's resources go beyond those of relations among states to ultimate ques-

39. See Report and Working Papers of a Panel of Experts, Decelopment and Environment (the "Founex Report" 1971) and Development and Enrironment, C.X. Doc. A/Conf. 48/10 (1972). See also Recommendations for Action, Nos. 102.09, in RErort, supra note 1 , at 54; pp. 1675-76 infra.

40. See pp. 1675-76, 1679 infra. In accordance with the so.called "Santo Domingo Doctrine," several Caribbean countries have claimed special sovercignty over the renewable and non-renewable natural resources (but not over the seas per se) in an area ad. jacent to their territorial seas which they have denominated the "patrimonial sea." See Specialized Conference of Caribbean Countries Concerning the Problems of the Sea: Declaration of Santo Domingo, done June 9, 1972, text in 66 AM. J. INTL L. 918 (1972). Iceland has also claimed a "fisheries zone" of fifty nautical miles off its coasts. See the Fisheries Jurisdiction Cases, pp. 1675-70 infra. In addition. Chile. Ecuador, and Peru have long claimed territorial seas of two hundred nautical miles. Sec Dec. laration of Santiago on the Maritime Zone, August 18, 1952, Eng. transl. in 4 M. Whiteman, Digest of INT'L L. 1089 (1968). Many other countries have extended their claims to various widths of territorial seas and fisheries zones. See S. OD.A, THE INTERnational Law of the Ocean Develobment 368 (1972).

41. See Agency for INTERNational DevelopMent, Feasinilmi Studies, Econonic aiid Technical Soundness Analyses, Captral Projects (1964, addendum 1972); International BANK FOR RECONSTRUCTION AND DEVELOMMENT, ENVIRONMENTAL HEALTH AND HUMAN ECOlogical Considerations in Economic DevelopMent Projects (1972). See also .1ID Manual Circulars Nos. 1221.2, Consideration of Environmental Aspects of Us.-. Issisted Capital Projects, Aug. 18, 1970, and 1214.1, Procedure for Environmental Review of Capital Projects, Sept. 20, 1971. The World Bank environmental guidelines are still "in-house" staff formulations and they have not yet been discusscd at an annual meeting. They are based largely, although not exclusively, on the AID standards. 
tions of human rights and individual well-being. Two additional factors enter the analysis: the degree to which nationality constitutes the vehicle of access to resources and the degree to which basic human rights define minimum benefit levels.

The general international law of nationality and jurisdiction over nationals provides little basis for asserting an individual right to specific resources. Subject to mutually advantageous conditions of reciprocity, states historically have possessed almost complete discretion in the determination of who are their nationals. ${ }^{22}$ Once having acquired a nationality, ${ }^{43}$ by virtue of that status and on the terms set by state governments nationals derive their claims of access to both exclusive and shareable resources.

Mitigating this rigid regime whereby the state and not the individual is the basic legal unit, there is the nascent international law of human rights. Initially, the right of human beings to some nationality is protected by customary international law. The Universal Declaration of Human Rights provides that, at a minimum, "everyone has the right to a nationality" and that "no one shall be arbitrarily deprived of his nationality nor denied the right to change his nationality." 4 It is not a treaty and therefore technically imposes no legal obligations. ${ }^{45}$ Furthermore, the individual is not entitled to any particular nationality or to any freedom to enjoy access to the resources of any particular nation-state. ${ }^{46}$ The right to some nationality, however, is at least theoretically established by the international community and from that follows the right of access of each person through some state to the shareable resources of the world. Beyond this minimum, the international community has begun to define other individual and collective human rights. The International Covenants on Civil and Political Rights and on Economic, Social and Cultural Rights ${ }^{47}$ seek to extend the right to a nationality to include effective participation in national

42. The Convention on Certain Questions relating to the Conflict of Nationality Laws, April 12, 1933, 179 L.N.T.S. 89, arts. 1, 2, for example, provides that "[i]t is for cach State to determine under its own law who are its nationals." It further specifies that "[a]ny question as to whether a person possesses the nationality of a particular State shall be determined in accordance with the law of that State."

43. Nationality may be acquired either at birth or subsequent to birth. States confer nationality at birth upon the basis of $j u s$ soli (the birth of such person within their territory or a place assimilated thereto) or jus sanguinis (the descent of such person from one of their nationals) or a combination of the two; states confer nationality at a later stage either by individual or collective nationalization. See Harvard RESEARCII, DRAFT ON THE LAW OF NATIONALITY art. 3 (1929).

44. G.A. Res. 217A, U.N. Doc. A/777 at 71, art. 15 (1948).

45. See U.S. Dep't of State, Universal Declaration of Human Rigitts, 9 In't'L ORG. \& CONF. SER. 20 (1948).

46. See P. Jessur, A Modern Law of Nations 72 (1948).

47. Annex to G.A. Res. 2200 A, 21 U.N. GAOR Supp. 16, at 49 (1966). The covenants are reproduced at 61 AM. J. INT'L L. 861, 870 (1967). See also European Convell. tion on Human Rights, November 4, 1950, Eur. T.S. No. 5, 213 U.N.T.S. 221. 
decision-making processes and in the sharing of national wealth. This concept has now been further enlarged in the specific context of the environment by the Stockholm Declaration, which proclaims as its primary goal man's "well-being and . . . enjoyment of basic human rights." 48

From the perspective of the quality of life and of securing fundamental human rights for great masses of people, another matter of utmost concern is the population problem. This is not only a matter of human resources, but also of numbers and movement of people in relation to resources. Although social scientists are far from agreement upon the specific parameters of the global population problem and the subject received little direct attention at Stockholm, some work is underway and a UN conference on population is scheduled for 1974..$^{\circ}$

To summarize, the traditional legal order of the environment is essentially a laissez-faire system oriented toward the unfettered freedom of states. States are basically unhampered in exercising competence, in formulating and implementing regulations, and in realizing benefit in the use and enjoyment of resources. Such limitations on freedom of action as exist in the traditional legal order have been formulated from perspectives other than the specifically environmental.

\section{Prescription: The Changing Perspective}

International law or the lack thereof is not a major causal factor of environmental problems today. Rather, technological development has made possible vastly increased rates of resource depletion, energy consumption, and population growth. The perceived imminence of critical pollution and scarcity thresholds has precipitated a sense of a global environmental crisis. ${ }^{50}$ It consequently is imperative that the legal order respond to these new conditions.

48. See Declaration, supra note 8, Preambular para. 1, at 1. In addition, Preambular paragraph 5 and Principle 16, both of which deal with population problems, declare respectively that "[o]f all things in the world, people are the most precious" and that demographic policies must be "without prejudice to basic human rights." Even more significantly, Principle I declares that man has "the fundamental right to freedom, equality and adequate conditions of life, in an environment that permits a life of dignity and well-being." Principle 19 explains the ultimate need "to protect and improve the environment in order to enable man to develop in every respect."

49. See REPORT, supra note 1, at 84; note 50 infra.

50. Some observers see increases in population in conjunction with growing per capita consumption as producing exponential effects on the rate of resource depletion. Others view the problem as essentially one of transition to new technologies such as fusion production of energy, mining of the oceans, and a "grcen revolution" in agriculture. See P. Ehrlich \& A. Ehrlich, Population, Resources, ENvironaient: Issues iv Human Ecology (1970); J. Forrester, World Dynamics (1971); D. Mfeadows, D. MEadows, J. Randers, IV. Behrens, The Limits to Growtil (1972); E. Poillinas, Polulation: A Clash of Prophets (1973); Choucri \& North, Dynamics of Intermational Conflicl, 24 WondD PoLirics 80 (Supp. 1972). 
There are indications that governments are becoming cognizant of the need for relief and are beginning to adjust the legal order. Change is necessary particularly with respect to the protection of the common resources, the ability of developing nations to realize benefit from the resources to which they have nominal right and access, and the right of the people themselves to realize such benefit.

\section{A. Competence Over Resources}

Given the established principles of "sovereignty" and the "sovereign equality" of states, it would be utopian to suppose that national governments would be willing to surrender any competence to apply law regarding their own exclusive resources. They have indicated some willingness, however, to comply with international prescription governing shared resources and even affecting certain ecological matters within their own national jurisdictions.

This promising trend was evidenced by the new prescriptions and recommendations adopted at the Stockholm Conference. The Action Plan for the Human Environment includes more than 200 proposals, many of which, if effectuated, will involve self-imposed limitations on some aspects of national lawmaking competence in the interests of the broader international community. ${ }^{51}$ Similarly, the Human Environment Declaration, although not technically a legally binding document affecting national sovereignty, is significant as a statement of fundamental principles and as an expression of the expectations and desires of 113 governments with regard to international action and regulation. ${ }^{52}$ Finally, the Stockholm Resolution on Institutional and Financial Arrangements establishes UN organizational channels for future cooperation and coordination.53 Although modest and underfinanced, this framework will permit future expansion of activities as national governments are stimulated by environmental developments and public pressures to further concrete international actions.

There are some less encouraging developments, including the nonparticipation of several Eastern bloc countries in the Human Environment Conference and attempts by some countries to expand their terri-

51. REPORT, supra note 1, at 8.60. The "Action Plan," inter alia, provides for the creation of an international monitoring system ("Earthwatch"), recommends the estab. lishment of a system for international registry of chemicals, recommends the cstablish. ment of a "Human Settlements Development Fund," and condemns nuclear weapons testing.

52. REPORT 2. In addition to its function as an inspirational and cducational device, the Declaration may provide the foundation for future negotiation of treaties codifying some of its principles.

53. REPORT 61. The Resolution established a Governing Council for Environmental - Programs, an Environment Secretariat with an Executive Director, an Environment Fund, and an Environmental Co-ordinating Board. 
torial seas or to extend exclusive competence over additional areas of the continental shelves. ${ }^{54}$ On balance, however, there is clearly more international awareness of the comprehensive character of problems of the human environment than there was before the Stockholm Conference was proposed.

\section{B. Employment in Use}

The extent to which the present legal order is state-centered is quite apparent in the principles governing the employment in use of resources. The rules restricting injurious use are almost all formulated so as to allow nation-states to protect themselves from environmental damage or to assign liability should such damage occur. ${ }^{\text {i5 }}$ Until recently, the shared resources per se have been virtually ignored. ${ }^{\text {s0 }}$ Self-defense, self-preservation, security, and good neighborliness are all defined in terms of a sovereign state "self." Contiguous zones are also designed to protect against injury to the territorial sea, internal waters, or land masses of coastal states. ${ }^{57}$

Moreover, the international case law of absolute liability is insufficient to protect common interests. ${ }^{58}$ To date it has been applied narrowly for damage inflicted by one country or by its nationals on the rights, property, or territory of another country, its nationals, or activities. ${ }^{59}$ In addition to these deficiencies in international proceedings, there have been no significant extensions of the jurisdiction of national courts to adjudicate questions involving spillover effects detrimental to the interests of other countries or to the international environment. And finally, the same limitation of state-centeredness has been incorporated into various treaties dealing with the use of resources. ${ }^{00}$

54. See notes 1 \& 12 supra. There have been other discouraging events, notably the disputes over fishing rights between Iceland and Great Britain and Cermany. See pp. 1675-76 infra.

55. See pp. 1665-66 supra.

56. The situation may be changing somewhat, at least in the context of the law of the sea. The new Ocean Dumping Convention, see note 63 infra, and several draft proposals presented to preparatory meetings for the UN Conference on the Law of the Sea demonstrate changing perspectives. See, e.g., the documents collected in 2 S. Lir, R. Churchile \& M. Nordeuist, supra note 12, at 737. See also Krueger, Evaluation of United States Ocean Policy, 17 McGin. L.J. 604 (1971); Lanctot, Marine Pollution: A Critigue of Present and Proposed International Agreements and Institutions-A Proposed Clobal Oceans' Environmental Regime, 24 Hastixas L. Rev. 67 (1973); Note, Exploitation of Seabed Mineral Resources-Chaos or Legal Order?, 58 ConNel. L. REv. 575 (1973).

57. See notes 22-24 supra.

58. This deficiency is recognized in the Human Environment Declaration. See p. 1674 infra.

59. See pp. 1665-66 supra.

60. For example, the Outer Space Treaty, supra note 17. art. 7 , provides for liability of a launching state "to another State . . or to its natural or juridical persons"; and even the IMCO "Private Law" Convention, supra note 26, art. 2, provides for shipowner liability only for oil pollution damage "caused on the territory including the territorial sea of a .... State." 
There are definite signs, however, that this legal order is changing. A broader perspective is evolving which will take account of spillover effects not previously cognizable under international law. The UN Declaration contains the principle that states "shall further the international law regarding liability and compensation for the victims of pollution and other environmental damage" that are "caused by activities within the jurisdiction or control of ... States to areas beyond their jurisdiction." ${ }^{1}$ This provision by definition applies to the res communes as well as the possessions of other states. The protection of the commons is also the stated objective of the Canadian law establishing a one hundred nautical mile "antipollution zone" in Arctic waters, a zone over which that country has assumed policing power, ${ }^{02}$ and it is the subject of the recent "Ocean Dumping" Convention. ${ }^{03}$ These prescriptions reflect analysis of environmental costs and benefits in terms much broader than the particular interests of sovereign states.

The principles facilitating productive and harmonious employment also display a fundamental, though not complete, state-centeredness. The traditional legal order has emphasized the facilitation of the use of these resources by states (and through states, by their nationals) rather than the preservation of the resources for the general benefit of present and future generations. ${ }^{64}$ Determination of jurisdiction over vessels, aircraft, and spacecraft is accomplished by their assimilation to the territory in which they are registered. $0^{05}$ This provides assurance that international law can be enforced anywhere in the world by at least one sovereign authority, but it does not ensure that it will be so implemented. The flying of "flags of convenience" is probably the most notorious device for avoidance of responsibilities under both national and international laws. ${ }^{66}$ Positive commitments by states to protect

61. RePort 7, Principle 22.

62. In April 1970 Canada enacted the Bill to Prevent Pollution of Arctic Waters. Arctic Waters Pollution Prevention Act of 1970, Can. Rev. Srat. c.47 (1969-70), text in 9 INT'L Legal Materials 543 (1970). Contemporaneously with the passage of the Arctic Waters Act, Canada modified its declaration under Article 36 of the Statute of the International Court of Justice to decline compulsory jurisdiction as regards issues arising out of its antipollution measures. See Canadian Declaration Concerning the Compulsory Jurisdiction of the ICJ, id. at 598. See also pp. 1678-79 infra.

63. Convention on the Prevention of Marine Pollution by Dumping of Wastes and Other Matter, done November 13, 1972, text in 11 INT'L LEGAL MA'TERIALS 1294 (1972). The convention prohibits the dumping at sea of specified deleterious materials and pro. vides that the dumping of any other material shall be regulated by a permit system (with criteria for the permits to be promulgated and regulations to be administered by national governments). At the time of this writing, states are in the process of ncgotiating a supplementary treaty to extend the scope of the Ocean Dumping Convention to cover additional substances.

64. See notes $31-33$ supra.

65. See notes $34-36$ supra.

66. See generally B. Boczex, Flacs of Convenience: An International Legat Study (1962). Ships are registered in Panama, Liberia, or Honduras (Panlibhon), usually to 
their long-term common interests and holistic human interests are required.

Some such commitments have already been made. The principles of "private international law" 07 and "responsibility of states" 08 have already been cited as limitations on the activities of sovereign states within their own national jurisdictions. It should also be noted that there are multiple sovereignties governing some activities and that this fact affords opportunities for balancing and counteracting the narrow perspectives of perceived short-term national interest. ${ }^{00}$

\section{Realization of Benefit}

On the issue of which states will actually derive benefit from the earth's resources, the internationalist perspective with its calculation of costs and benefits on a global scale is least far advanced. There are a few signs, however, that nations are beginning to face the broader economic and social dimensions of their activities.

A symbolic acknowledgment of the equitable claims of the developing nations to realization of benefits was the decision to locate the new United Nations environmental unit in Kenya. The General Assembly's choice of Nairobi over the administratively more reasonable alternatives of New York and Geneva is defensible on broad utilitarian grounds, chiefly psychological and political. ${ }^{70}$

In much more concrete form the International Court of Justice (ICJ) now faces aspects of the realization problem in the new Fisheries Jurisdiction Case. The United Kingdom and the Federal Republic of Germany have challenged Iceland's claim to extend its exclusive fisheries jurisdiction to a zone of fifty nautical miles around the island. ${ }^{72}$ At the

avoid wage or tax legislation in the countries of their owners. Even were such advantages to disappear, however, the continuance of the practice to avoid antipollution or other environmental regulations is easily foreseeablc.

67. See note 37 supra.

68. See note 38 supra.

69. For example, if Panlibhon or other particular flags are used to aroid international or national environmental regulations, see note 66 supra, the states whose nationals own those ships can still directly regulate many aspects of the behavior of their nationals. Multiple jurisdictions are not unfamiliar to international law; the traditional law of the sea, for example, provides for universal jurisdiction with regard to crimes of piracy and for concurrent jurisdiction of the coastal and flag states under certain other circumstances. See note 34 supra.

70. This decision was reached by the UN General Assembly, to which the choice of a location had been referred by the Stockholm Conference. See Nairobi vs. New Yorl, N.Y. Times (editorial), November 15,1972 , at 46 , col. 3 .

71. On April 14, 1972, the United Kingdom filed in the Registry of the ICJ an application instituting proceedings against Iceland; on June 5, 1972, the Federal Republic of Germany instituted similar proceedings. The underlying agreements upon which these suits are grounded are to be found at 397 U.N.TS. 275 (1961) and 409 U.N.T.S. 47 (1961). The Icelandic Resolution of the Althing on Fisheries Jurisdiction. 
time of this writing, the ICJ has issued a preliminary injunction against Iceland ${ }^{72}$ and has decided that it has jurisdiction to adjudicate both controversies, ${ }^{73}$ but it has not yet rendered a judgment on the merits.

It can be argued that the extension of such zones might protect large areas of the seas from resource depletion, in addition to protecting the interests of less economically advanced states which cannot yet effectively compete for their "share" of the shareable resources. ${ }^{74}$ Fisheries zones clearly would represent an extension of unilateral application of law, but the situation is ambiguous with respect to prescription. There are a number of explicitly environmental dimensions to the question: First, whether countries possessing these zones will be willing to assent to multilateral prescription of conservation standards; second, whether, until and unless multilateral agreement is reached, the added control and economic incentive that may be derived from regulating or licensing will impel these countries to give greater priority to environmental variables in their unilateral prescriptions. Only if both are true would these zones be analogous to the Canadian position on Arctic waters. In view of changing perspectives on international affairs, it may be expected that the ICJ will at least consider the environmental dimension as one factor determining its decisions.

Finally, however insecure the position of the developing countries, even less progress has been made toward ensuring that the people themselves reap the benefits of the world's resources. It is at least a hopeful sign that the first principle of the Stockholm Declaration states:

Man has the fundamental right to freedom, equality and adequate conditions of life, in an environment of a quality that

which extended the fisheries limits to 50 miles, appears in 11 INr'L LEGAL MATERIALS 649 (1972); and Iceland's Regulations Concerning the Fishery Limits off Iccland appears in id. at 1112. See also Belgium-Iceland: Agrecment on Fishing within Fifty Mile Limit off Iceland, $i d$. at 941 .

72. Order Concerning the Request for Indication of Interim Measures of Protection, August 17, 1972, text in 11 Inr'. Legal Materials 1069 (1972). See also Order Con. cerning the Question of the Court's Jurisdiction, id. at 1077. The World Court issued similar orders concerning interim measures and jurisdiction in the Fisherics Jurisdic. tion Case of Germany v. Iceland. See id.

73. Fisheries Jurisdiction Case (United Kingdom v. Iccland) and Fishcries Juris. diction Case (Federal Republic of Germany v. Iceland ICJ, judgments of February 2, 1973). In each instance the court reached its determination of jurisdiction by a vote of 14 to 1 (Judge Padilla Nervo dissenting).

74. The Fisheries Case (United Kingdom v. Norway), [1951] I.C.J. 116, which arosc out of a dispute over fishing rights of British vessels in Norwegian coastal waters, inight provide a precedent. The central issue in the case was the validity under international law of a Norwegian Royal Decree of 1935 which delimited Norway's exclusive fishing zones off its northern coast. In holding for Norway the ICJ attached considerable significance to the fact that the Norwegians were poor and needed the fish:

Finally, there is one consideration not to be overlooked, the scope of which ex.

tends beyond purely geographical factors: that of certain cconomic interests peculiax

to a region, the reality and importance of which are clearly evidenced by a long usage. [1951] I.C.J. at 133 . 
permits a life of dignity and well-being, and he bears a solemn responsibility to protect and improve the environment for present and future generations. ${ }^{\mathrm{i}}$

While such an optimal future must be seen as a distinct long-range goal, a far more effective regime of international environmental law than presently exists can in the meantime be developed by persuading national governments to measure the damage they do to the environment and the costs of avoiding such damage in terms of global impact. The shift to better environmental perspectives, in other words, need not await either world federalism or the full realization of human rights and dignity.

\section{Application: The Vehicles of Change}

This necessary shift in perspective need not await the formation of broad-based international regulatory bodies. All governments should collectively apply and enforce the principles and regulations of international environmental law, and in some narrowly defined areas they may well do so. Given the difficulty of obtaining such concerted action, however, even under United Nations auspices, it is necessary to look elsewhere for the principal effort to apply international environmental law.

One promising alternative or supplement to full global cooperation lies in regional organization. A great many ecological problems are predominantly regional in scale and can most effectively be understood and dealt with at that level. A variety of regional bodies already possess delegated authority to formulate principles dealing with various aspects of resource planning and development. ${ }^{\text {To }}$ These organizations might be capable of assuming additional responsibilities for the application of environmental prescriptions within their areas of competence.it

75. REPORT, supra note 1 , at 4 .

76. Four main types of regional bodies are relevant in this context: regional bodies within the UN framework of broad competence (e.g., the Regional Economic Commis. sions), United Nations regional bodies with functional specialties (e.g., the Specialized Agencies each have regional networks), multipurpose regional bodies whose mandate includes environmental matters (e.g., the OECD, CNE.1, N.ITO, O.1S), and single.focus non-UN bodies (e.g., river commissions such as the International Joint Commission and fisheries councils such as exist for the Meditermancan and Indo-Pacific .Ireas). For a useful catalogue of regional and other environmental organizations, see ENSIRONMENTAL Policy Division, CoNgressional Research Service, Library of CoNGress, 92d CoNc., 1st Sess., Environmental Activities of International Organizitions (Comm. l'rint 1971).

77. The present and potential vehicles of change are, of course, not lituited to re: gional, intergovernmental organizations. International actors of all types-govermmental and nongovernmental, professional and nonprofessional, public, private, and mixed-

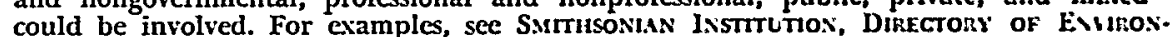
MeNTal Moxitoring SysteMs (1970) and U.N.C.H.E. Bibliography, U.S. Doc. A/Conf. 48/13/Rev. (1972). 
In the final analysis, however, the primary responsibility for application of international environmental prescriptions must still fall upon individual state governments. To a large extent, this simply entails abiding by the prescriptions collectively developed. States, for example, have delineated their individual responsibility in the new Ocean Dumping Convention, which provides for national prohibition, permit systems, monitoring, and policing of waste disposal at sea. ${ }^{78}$ Under a recent UNESCO convention states have also recognized their duty of "ensuring the identification, protection, conservation, presentation and transmission to future generations" of the world's cultural and natural heritage, and they have bound themselves to takc "effective and active measures" toward these ends..$^{70}$

Full and prompt application of environmental prescriptions may nevertheless require more radical solutions by concerned states-at least until adequate international action is taken. The controversial Canadian Arctic "anti-pollution zone" is an example of such unilateral action. ${ }^{80}$ Within that zone, Canada has forbidden the deposit of wastes and other forms of pollution, imposed absolute civil liability and penalties for violations, and authorized "pollution prevention officers" to carry out extensive inspections and other regulatory measures. Canada bases its action not on an extension of sovereignty, ${ }^{81}$ but rather on general theories of impact territoriality and state security, ${ }^{82}$ on an

78. See note 63 supra; AM. SOc. INT'L LAw, THE QUestion of AN OCEAN Duminc Conventron (1972).

79. UNESCO Convention for the Protection of the World Cultural and Natural Heritage, adopted November 16, 1972, arts. 4 \& 5, text in 11 INT'L LeGAL MATERIALs 1358 (1972). The same UNESCO General Conference which adopted this convention also unanimously adopted a companion Recommendation Concerning the protection, at a National Level, of the Cultural and Natural Heritage, id. at 1367. See Convention on Wetlands of International Importance, $i d$. at 963.

80. For a heated exchange of views between the United States and Canada concerning this legislation, see U.S. Statement on Canada's Proposed Legislation, 9 IN't' Legal Materials 605 (1970) and Canadian Reply to the U.S. Government, id. at 607. See Becsley, Rights and Responsibilities of Arctic Coastal States: The Canadian V'ien', 3 J. Maritime L. \& Commerce (1971); Legault, Canadian Arctic Waters Pollution Pre' vention Legislation, in The LAw of The Sea: the United Nations and OcEaN MaNAGement 294 (Proceedings of the 5th Annual Conf. of the Law of the Sea Institute 1970). Cf. Bilder, The Canadian Arctic Waters Pollution Prevention Act: New Stresses on the Law of the Sea, 69 Mich. L. Rev. 1 (1970); Henkin, Arctic Anti-Pollution: Docs Canada Make-or Break-International Law?, 65 AM. J. INT'L L. 131 (1971).

81. See Canadian Prime Minister's Remarks on the Proposed Legislation, 9 Inr'L Legal Materials 601 (1970).

82. The Canadian Reply to the U.S. Government, supra notc 80, at 607, for example, pointed out, "For many years, large numbers of states have asserted various forms of limited jurisdiction beyond their territorial sea over marine areas alljacent to their coasts." It then went on to explicate that "[i]t is the further view of the Canadian Government that a danger to the environment of a state constitutes a threat to its security." Id. at 608 . 
archipelagic principle, ${ }^{83}$ and on the special characteristics of the situation. ${ }^{84}$

Regulated "fishing zones" and other "resource zones," such as those currently claimed by Iceland and several Latin American countries, ${ }^{85}$ may be another answer to the global environmental imperative. Whether they are, on balance, justified is not yet clear. At least they represent efforts to regulate the use of common resources. If some such measures are not taken by sovereign states-collectively if possible, but individually if necessary-even the minimum goals of the Stockholm Conference will never be realized.

It would be naive to ignore the grave problems connected with this approach; unilateral state action and multilateralism or internationalism are not always readily compatible. National actions for the protection of the common resources may interfere with other aspects of international law. The Canadian legislation itself interferes with certain traditional freedoms of shipping and oil transport on the high seas. ${ }^{86}$ Even internal environmental measures may conflict with the interests of other states or private parties. The United States safety and emission standards for automobiles, for example, have potentially devastating effects on the exports of foreign manufacturers. ${ }^{87}$ National

83. In introducing the Arctic Waters Act in the Canadian House of Commons, Sacretary of State for External Affairs Mitchell Sharp several times referred to the "Aretic archipelago." While emphasizing that Canada has always regarded these as Canadian waters, he reaffirmed that the legislation did not represent an aseertion of general sovereignty over the area. See PARL. DEB., H.C. 5948 (April 16, 1970 (Can.)). Sec also id. at 6015 (April 17, 1970 (Can.)).

84. The argument is not uncontested. During the March 1973 debates in Subcommittec 3 on Marine Pollution of the UN "Seabeds" Committee (Committce on the Peaceful Uses of the Sea-bed and the Ocean Floor Bejond the Limits of National Jurisdiction), for example, the Legal Advisor of the Canadian Department of External Affairs pointed to recent British legislation as supportive of his nation's position. This claim was strongly contested by the British delegation.

The Oil in Navigable Waters Act 1971, c. 21, defines offenses and establishes liability for oil pollution under various circumstances. The radical nature of the legislation is the provision that the British Government may by Order in Council, and "in such cases and circumstances as may be specified in the order," apply the Act to a ship:

(a) which is not a ship registered in the United Kingdom; and

(b) which is for the time being outside the territorial waters of the United Kingdom.

Id. $\S 16$. The legislation is in implementation of the 1969 Brussels Convention, supra note 26, which has not yet come into force. See also The Prevention of Oil Pollution Act 1971 c.60; The Merchant Shipping (Oil Pollution) Act 1971, c39. For a bricf discussion of the Canadian view of this British legislation, sce Johnston, Ifarine Pollution Control: Law, Science and Politics, 28 INT'L J. 69, 85 (1972).

85. See pp. 1669, 1675-76 supra.

86. See Canadian Prime Minister's Remarks on the Proposed Legislation, supra note 81 , at 602 .

87. The safety and emission standards which have been enacted by the United States Congress are applicable to automobiles imported into the United States. 42 U.S.C. $\$ 1857 \mathrm{f}-2(\mathrm{~b})$ (2) $(1970)$. Foreign manufacturers may not be able to participate in the shaping of U.S. legislation or share in the development of the necessary technolog): Their export problems are further complicated by the fact that other countries are developing their own standards for auto safety and pollution and that the lavis are not uniform. 
environmental regulations for the protection of common and internal resources may also create countervailing duties or give rise to other problems under the General Agreement on Tariffs and Trade. ${ }^{88}$ And finally, all the measures considered above raise procedural questions of what international and national courts and other tribunals shall or may assume jurisdiction over environmental disputes that arise. ${ }^{80}$

\section{Conclusion}

Aside from the need for further information and exchange of intelligence, two main sets of conclusions result from the above analysis: First, in the prescription of international environmental law, multilateral initiatives aimed at reducing the state-centeredness and increasing the environmental responsiveness of the legal order are developing and deserve every encouragement. They must be supplemented by the concurrent adoption of sound ecological principles by national political processes. Second, in its application, multilateral action at the global and regional level is to be hoped for as the long-term solution. Given the character of the existing international system, the most immediately promising course for achieving environmental protection appears to be increased assumption by individual states of the responsibilities for implementation of collectively derived prescriptions or, in their absence, of reasonable unilateral standards and criteria.

In particular cases the validity of policies and actions must be judged not only by their compatibility with established norms and standards, but also by their desirability in light of environmental conditions developing in advance of formalized legal processes. In all circumstances and on the part of all actors, a conscious and systematic attempt must be made to take account of the environmental dimensions to every ongoing political process.

88. Article $I$ of the General Agreement on Tariffs and Trade (GATT) states its fundamental principle as nondiscrimination in world trade through general and III. conditional "most-favored-nation" treatment. Agreement concluded October 30, 19:17, 61 Stat. pts. 5-6 (1947), T.I.A.S. No. 1700, 55-61 U.N.T.S. (1947); appearing as amended [1951] 2 U.S.T. 1767, T.I.A.S. No. 3930, 278 U.N.T.S. 168 (1957). Article 20 on "General Exceptions," however, allows adoption or enforcement of measures "'necessary to pro. tect human, animal, or plant life or health." If Article 20 is broadly interpreted to include the diffuse area of "environmental" regulations, the "exception" may very well swallow the rule.

89. International lawyers increasingly have been turning their attention to the matter of international and national machinery for the settlement of international environmental disputes. See, e.g., Jessup, Do New Problems Need New Courts?, 65 Proceedincs, Am. Soc. INT'L LAW 261 (1971). The UN Institute for Training and Rescarch (UNITAR) has recently decided to undertake a study of the matter. 